\title{
Characterization of preptin-induced insulin secretion in pancreatic $\beta$-cells
}

\author{
Kai-Chun Cheng, Ying-Xiao Li, Akihiro Asakawa, Miharu Ushikai, Ikuo Kato', Yuki Sato', \\ Juei-Tang Cheng ${ }^{2}$ and Akio Inui \\ Department of Psychosomatic Internal Medicine, Graduate School of Medical and Dental Sciences, Kagoshima University, 8-35-1 Sakuragaoka \\ Kagoshima 890-8520, Japan \\ ${ }^{1}$ Department of Bioorganic Chemistry, Faculty of Pharmaceutical Sciences, Hokuriku University, Kanazawa 920-1180, Japan ${ }^{2}$ Department of Medical Research, \\ Chi-Mei Medical Center, Tainan 710-04, Taiwan \\ (Correspondence should be addressed to A Inui; Email: inui@m.kufm.kagoshima-u.ac.jp)
}

\begin{abstract}
We aimed to characterize the effects of preptin on insulin secretion at the single-cell level, as well as the mechanisms underlying these changes, with respect to regulation by intracellular $\mathrm{Ca}^{2+}\left[\mathrm{Ca}^{2+}\right]_{i}$ mobilization. This study assessed the effect of preptin on insulin secretion and investigated the link between preptin and the phospholipase C (PLC)/protein kinase C (PKC) pathway at the cellular level using fura-2 pentakis(acetoxymethyl) ester-loaded insulin-producing cells (Min 6 cells). Our results demonstrate that preptin promotes insulin secretion in a concentration-dependent manner. Using a PLC inhibitor (chelerythrine) or a PKC inhibitor (U73122) resulted in a concentration-dependent decrease in insulin
\end{abstract}

secretion. Also, preptin mixed with IGF2 receptor (IGF2R) antibodies suppressed insulin secretion in a dose-dependent manner, which indicates that activation of IGF2R is mediated probably because preptin is a type of proIGF2. In addition, preptin stimulated insulin secretion to a similar level as did glibenclamide. The activation of PKC/PLC by preptin stimulation is highly relevant to the potential mechanisms for increase in insulin secretion. Our results provide new insight into the insulin secretion of preptin, a secreted proIGF2-derived peptide that can induce greater efficacy of signal transduction resulting from PLC and PKC activation through the IGF2R.

Journal of Endocrinology (2012) 215, 43-49

\section{Introduction}

Preptin is a novel peptide that can be purified from the secretory granules of cultured murine $\beta$-cells. It is 34 amino acids long and corresponds to Asp69-Leu102 of proinsulinlike growth factor 2 (proIGF2E; Buchanan et al. 2001). This peptide belongs to the insulin, gastric intestinal peptide, and endocrine peptide family. Several studies have shown that preptin can enhance insulin secretion, while infusion of isolated pancreases with preptin antibodies significantly reduces glucose-mediated insulin secretion (Yang et al. 2009).

Insulin secretion can be stimulated by both nutrient and non-nutrient secretagogues. Non-nutrient insulin secretagogues may modulate $\beta$-cell ion channels through the cAMP or phospholipase C (PLC) pathways (Harndahl et al. 2002), or they may increase the release of arachidonic acid (Konrad et al. 1994), thereby sensitizing these channels to primary stimuli. Neurotransmitters and hormones, such as acetylcholine, arginine vasopressin, or bombesin, that activate receptors coupled to the $\mathrm{Ca}^{2+}$-phosphoinositide (PI) pathway cause a rise in the concentration of cytosolic-free $\mathrm{Ca}^{2+}\left(\left[\mathrm{Ca}^{2+}\right]_{\mathrm{i}}\right)$ and stimulate insulin secretion from normal and transformed $\beta$-cells in the presence of glucose (Garcia et al. 1988, Gao et al. 1990, Regazzi et al. 1990, Schofl et al. 1995). Several lines of evidence, mainly from non-excitable cells, suggest that protein kinase $\mathrm{C}$ (PKC), which is coactivated upon stimulation of receptors coupled to the $\mathrm{Ca}^{2+}-\mathrm{PI}$ pathway, may regulate PLC-linked $\mathrm{Ca}^{2+}$ oscillations via a negative feedback loop (Woods et al. 1987, Cuthbertson \& Chay 1991, Bird et al. 1993, Kawabata et al. 1996, Thomas et al. 1996, Codazzi et al. 2001, Young et al. 2002).

The aim of this study is to characterize the effect of preptin on insulin secretion and to investigate the potential mechanism(s) responsible for this action of preptin.

\section{Materials and Methods}

Peptide synthesis and preparation of drugs

Mouse preptin (DVSTSQAVLPDDFPRYPVGKFFQYDTWRQSAGRL) was synthesized by a solid-phase methodology with a fluorenylmethyloxycarbonyl strategy using an automated peptide synthesizer (Model Pioneer; Applied Biosystems) and the crude peptide was purified by a reverse-phase HPLC (Delta 600 HPLC System; Waters, MA, USA) on a column of Develosil ODS-HG-5 
$(2 \times 25 \mathrm{~cm}$; Nomura Chemical, Aichi, Japan). The homogeneity of the purified peptide was confirmed by analytical HPLC, MALDI-TOF MS, and sequence analysis.

\section{Determination of postprandial blood glucose in rats}

Animals Male Wistar rats weighing 150-250 g were obtained from the Animal Center of Chi-Mei Medical Center. Rats were housed in a temperature-controlled room $\left(25 \pm 1^{\circ} \mathrm{C}\right)$ and kept on a $12 \mathrm{~h}$ light: $12 \mathrm{~h}$ darkness cycle (light on at $0600 \mathrm{~h}$ ). Water and standard laboratory diet were freely available throughout. Studies were carried out in accordance with the Declaration of Helsinki and with the Guide for the Care and Use of Laboratory Animals as adopted and promulgated by the National Institutes of Health. The animal experiments were approved by the Regional Ethics Committee for Animal Research in Chi-Mei Medical Center (Tainan, Taiwan).

Effect of preptin on postprandial blood glucose was carried out mainly according to a previous report (Baron 1998). A total of 16 rats were segregated into two groups of eight animals each. After 12-h fasting, blood samples were withdrawn from tail vein and glucose in plasma was estimated for basal reading $(0 \mathrm{~min})$. Then, one group of animals was treated with preptin $(0.1 \mathrm{mg} / \mathrm{kg})$ through i.v. injection into the tail vein. Another group receiving the same injection of vehicle at the same volume was taken as control. Thirty minutes after the treatment, glucose solution at a dose of $1 \mathrm{~g} / \mathrm{kg}$ body weight was administered orally. Blood samples were withdrawn at the indicated time after the oral glucose load and the glucose in plasma was estimated. All experiments were carried out in animals under anesthesia with $2 \%$ isoflurane. The insulin level in blood was determined using ELISA kit (Mercodia, Uppsala, Sweden).

\section{Cell line and culture conditions}

Mus musculus insulinoma cell line Min 6 cells (from Prof. Susumu Seino, Kobe University, Kobe, Japan) were cultured in a RPMI 1640 medium (Gibco BRL) supplemented with 10\% FCS (Biologic Industries, Kibbutz Beit Haemek, Israel), penicillin (100 IU/ml), streptomycin $(100 \mathrm{mg} / \mathrm{ml})$ (both from Sigma), and amphotericin B $(2 \cdot 5 \mathrm{mg} / \mathrm{ml}$; Gibco). The cells were subcultured once weekly by trypsinization (Gibco), and the medium was changed every 3-4 days. For the experiments, the cells were seeded on round (25 mm diameter) sterile glass coverslips and cultured for 48-72 h in RPMI 1640 medium supplemented as earlier.

\section{Measurement of insulin secretion}

To explore whether preptin has direct effects on insulin secretion, we performed in vitro secretion experiments using Min 6 cells. Min 6 cells were seeded at $1 \times 10^{5}$ cells per well density in $1 \mathrm{ml}$ DMEM in 12-well plates $24 \mathrm{~h}$ before glucosestimulated insulin secretion (GSIS). Briefly, on the day of the study, cells were pretreated with low glucose $(2 \cdot 0 \mathrm{mM})$ DMEM for $2 \mathrm{~h}$ and then replaced with medium consisting $1 \%$ BSA. Before GSIS, isolated islets were washed with low glucose $(2.0 \mathrm{mM})$ medium. The cells for GSIS were treated with chelerythrine (PKC inhibitor) or U-73122 (PLC inhibitor) (both from RBI; Natick, MA, USA) at desired concentrations or vehicle at same volume as control for $30 \mathrm{~min}$. Then, all cells were incubated with preptin at desired concentrations for $1 \mathrm{~h}$. Also, glibenclamide (Sigma) was treated with cells in another group in the same manner. After the collection of media to store at $-20^{\circ} \mathrm{C}$, insulin levels in the media were determined using an insulin ELISA kit (Mercodia).

\section{Measurement of intracellular calcium concentrations}

The changes in the intracellular calcium concentration were detected using the fluorescent probe fura-2 (Lee et al. 2007). Min 6 cells were placed in buffered physiological saline solution containing $140 \mathrm{mM} \mathrm{NaCl}, 5.9 \mathrm{mM} \mathrm{KCl}$, $1.2 \mathrm{mM} \mathrm{CaCl}_{2}, 1.4 \mathrm{mM} \mathrm{MgCl}_{2}, 11.5 \mathrm{mM}$ glucose,
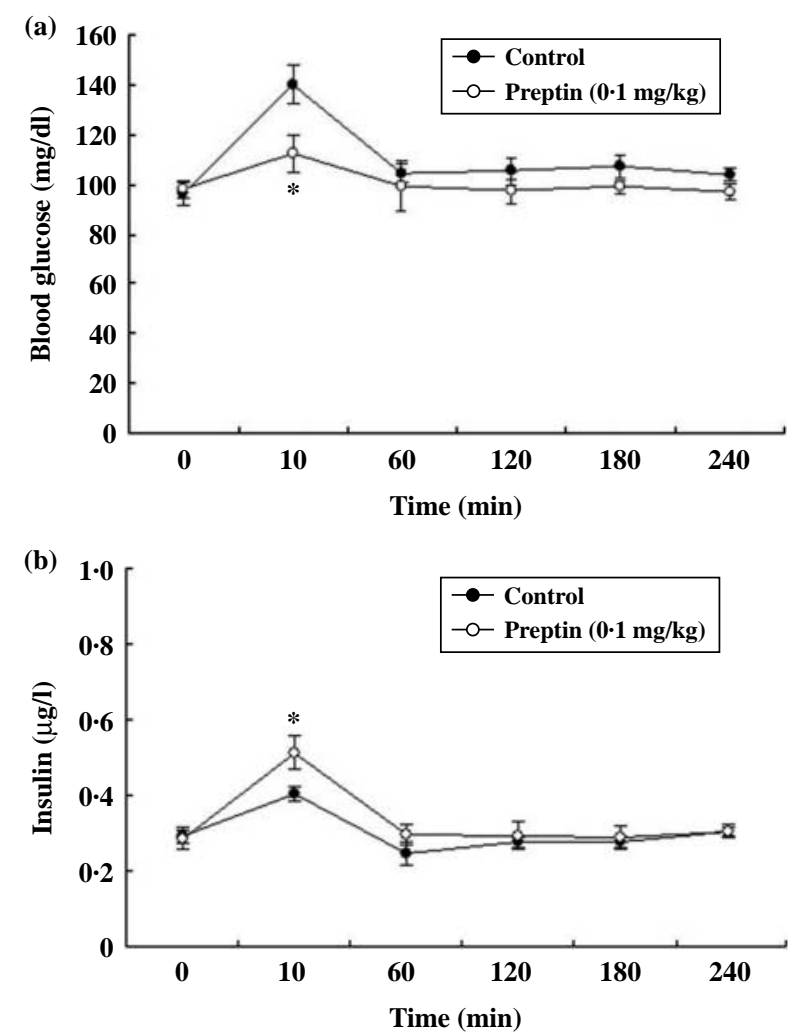

Figure 1 Effects of preptin on changes in blood glucose and insulin levels in fasted Wistar rats after glucose $(1 \mathrm{~g} / \mathrm{kg})$ loading. (A) Changes of blood glucose and (B) changes of blood insulin. There was a decrease in blood glucose and increase in blood insulin by i.v. injection of preptin $(0 \cdot 1 \mathrm{mg} / \mathrm{kg})$ in fasting rats. Each point represents mean \pm S.E.M. from eight rats. ${ }^{*} P<0.05$ vs compared with control group. 
$1.8 \mathrm{mM} \mathrm{Na}_{2} \mathrm{HPO}_{4}$, and $10 \mathrm{mM}$ Hepes-Tris, to which $5 \mu \mathrm{M}$ fura- 2 was added, and the cells were incubated for $1 \mathrm{~h}$ in humidified $5 \% \mathrm{CO}_{2}$ and $95 \%$ air at $37^{\circ} \mathrm{C}$. The cells were washed and incubated for an additional $30 \mathrm{~min}$ in physiological saline solution (PSS). The Min 6 cells were inserted into a thermostated $\left(37^{\circ} \mathrm{C}\right)$ cuvette containing $2 \mathrm{ml}$ calcium-free PSS and various doses of preptin or inhibitor as indicated. The fluorescence was continuously recorded using a fluorescence spectrofluorometer (Hitachi F-2000). Values of $\left[\mathrm{Ca}^{2+}\right]_{i}$ were calculated from the ratio $R=\mathrm{F} 340 / \mathrm{F} 380$ by the formula $\left[\mathrm{Ca}^{2+}\right]_{\mathrm{i}}=K_{\mathrm{d}} B\left(R-R_{\min }\right) /\left(R_{\max }-R\right)$, where $K_{\mathrm{d}}$ is $225 \mathrm{nM}, \mathrm{F}$ is the fluorescence, and $B$ is the ratio of the fluorescence of the free dye to that of the $\mathrm{Ca}^{2+}$-bound dye measured at $380 \mathrm{~nm} . R_{\max }$ and $R_{\min }$ were determined in separate experiments using preptin to equilibrate $\left[\mathrm{Ca}^{2+}\right]_{\mathrm{i}}$ with ambient $\left[\mathrm{Ca}^{2+}\right]\left(R_{\max }\right)$ and adding $0.1 \mathrm{mM} \mathrm{MnCl}_{2}$ and $1 \mathrm{mmol} / 1$ EGTA $\left(R_{\min }\right)$. Background autofluorescence was measured in unloaded cells and was subtracted from all measurements.

\section{Western blotting analysis}

Specific protein expression levels in Min 6 cells were determined by western blotting analysis. Proteins extracted using radioimmunoprecipitation assay buffer were separated by SDS-PAGE, electrotransferred, and immobilized on a nitrocellulose membrane. The membrane was blocked with $5 \%$ nonfat milk in PBS containing $0 \cdot 1 \%$ Tween 20 (PBS-T) and incubated for $2 \mathrm{~h}$. The membrane was then washed in PBS-T and hybridized with IGF2 receptor (IGF2R) antibody (Santa Cruz), which were diluted to a suitable concentration in PBS- T for $16 \mathrm{~h}$. Incubation with secondary antibodies and the detection of the antigen-antibody complex were performed using an ECL kit (Amersham Biosciences). Immunoblot densities were quantified using a laser densitometer.

\section{Statistical analysis}

Data are expressed as the mean \pm S.E.M. for the number $(n)$ of samples in one group as indicated. Statistical analysis was carried out using one-way ANOVA analysis and Newman-Keuls post-hoc analysis. A $P$ value of 0.05 or less was considered significant.

\section{Results}

Effect of preptin on blood glucose and insulin levels in rats challenged with glucose

In fasted Wistar rats, preptin failed to affect the blood glucose level in preliminary experiments. Thus, we gave preptin to fasted Wistar rats receiving a $1 \mathrm{~g} / \mathrm{kg}$ glucose challenge to investigate the effects of preptin. Preptin i.v. injected into rats resulted in a frank decrease in blood glucose

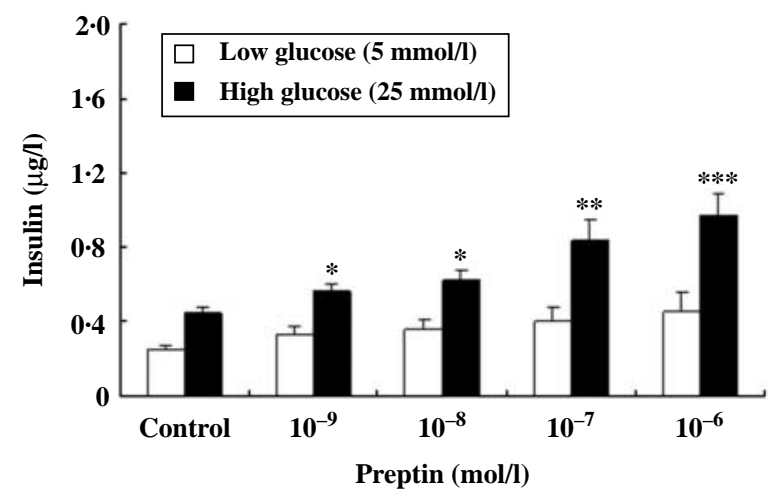

Figure 2 Preptin increased insulin secretion in Min 6 cells. In the presence of $25 \mathrm{mM}$ glucose, insulin secretion was significantly potentiated by preptin from $10^{-9}$ to $10^{-6} \mathrm{~mol} / \mathrm{l}$, but it was not changed in medium containing low glucose $(5 \mathrm{mM})$. Results expressed as mean \pm s.E.M. are obtained from six independent experiments. ${ }^{*} P<0 \cdot 05,{ }^{* *} P<0 \cdot 01,{ }^{* * *} P<0 \cdot 005$ compared with control group.

and a marked increase in blood insulin as compared with the vehicle-treated group (Fig. 1).

\section{Effect of preptin on insulin secretion in Min 6 cells}

To determine the effect of preptin on insulin secretion, we used Min 6 cells to investigate insulin secretion under highglucose conditions $(25 \mathrm{mmol} / \mathrm{l})$ because preptin failed to modify insulin secretion in this cell line in normal medium. The glucose-induced insulin release was potentiated by preptin in a concentration-dependent manner: preptin at a concentration of $10^{-9}, 10^{-8}, 10^{-7}$, and $10^{-6} \mathrm{~mol} / 1$ increased insulin release significantly $(P<0 \cdot 05)$, while preptin at a concentration higher than $10^{-6} \mathrm{~mol} / 1$ showed same action as that at $10^{-6} \mathrm{~mol} / 1$ (Fig. 2). These results indicated that preptin enhances glucose-induced insulin release from pancreatic $\beta$-cells in a concentration-dependent manner.

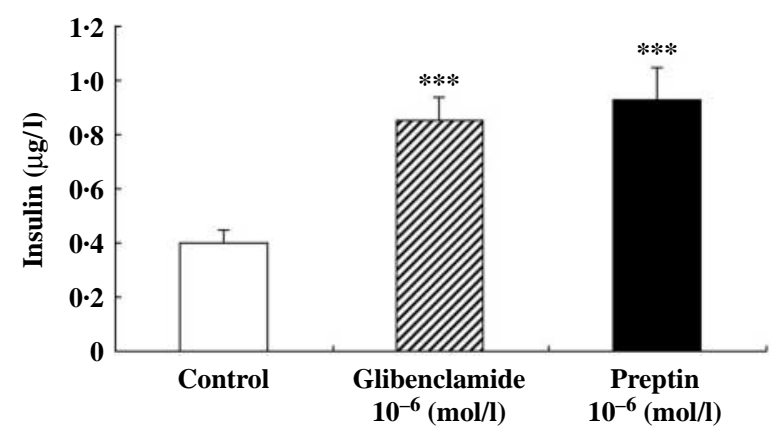

Figure 3 Under high-glucose conditions $(25 \mathrm{mmol} / \mathrm{l})$, insulin secretion was markedly raised in Min 6 cells treated with glibenclamide $\left(10^{-6} \mathrm{~mol} / \mathrm{l}\right)$ compared with that induced by preptin $\left(10^{-6} \mathrm{~mol} / \mathrm{l}\right)$. ${ }^{* * *} P<0 \cdot 005$ compared with control group. 
Comparison of the effects of glibenclamide and preptin on insulin secretion

In general, glibenclamide is widely used to increase insulin secretion. Glibenclamide increased insulin secretion from Min 6 cells significantly at a concentration of $10^{-6} \mathrm{~mol} / \mathrm{l}$. Preptin at a concentration of $10^{-6} \mathrm{~mol} / 1$ increased insulin secretion to a level similar to that induced by glibenclamide at $10^{-6} \mathrm{~mol} / \mathrm{l}$ (Fig. 3).

Changes in $\left[\mathrm{Ca}^{2+}\right]_{i}$ caused by preptin in Min 6 cells

We tested the role of intracellular calcium ions $\left(\left[\mathrm{Ca}^{2+}\right]_{\mathrm{i}}\right)$ in insulin secretion caused by preptin. After incubation with preptin, the concentration of $\left[\mathrm{Ca}^{2+}\right]_{i}$ was significantly raised in Min 6 cells. Preptin (from $10^{-9} \mathrm{~mol} / \mathrm{l}$ ) produced a concentration-dependent increase in $\left[\mathrm{Ca}^{2+}\right]_{\mathrm{i}}$ concentration in Min 6 cells (Fig. 4).

\section{Identification of the presence of IGF2R in Min 6 cells}

Western blotting analysis of the membrane fraction prepared from Min 6 cells showed the expression of IGF2R (Fig. 5). The presence of IGF2R in pancreatic $\beta$-cells can thus be identified.

Effect of IGF2R antibodies on the action of preptin in Min 6 cells In the presence of antibodies specific to IGF2R, the effects of preptin were abolished (Fig. 6). The increase in insulin secretion and the higher calcium ion concentration caused by preptin were both markedly inhibited by the antibodies specific to IGF2R. This result implied that IGF2R is a mediator of the actions of preptin.

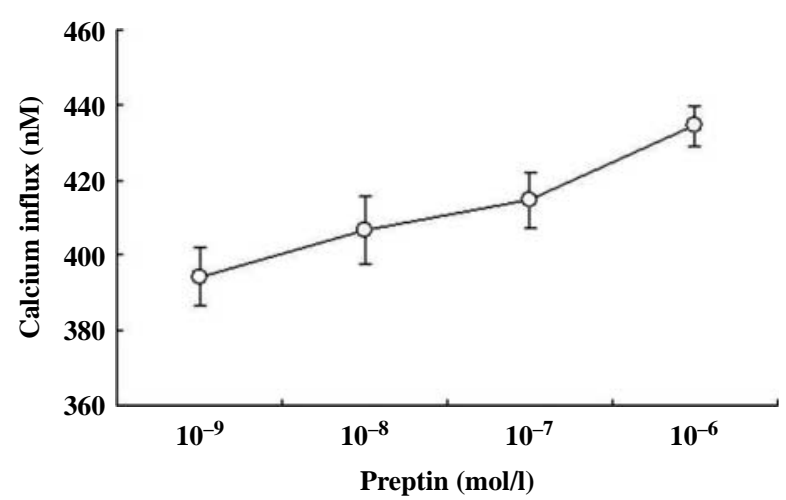

Figure 4 Increase in calcium influx by preptin in Min 6 cell under high-glucose conditions $(25 \mathrm{mmol} / \mathrm{l})$. The $\left[\mathrm{Ca}^{2+}\right]_{i}$ levels determined by fura- 2 were concentration dependently increased by preptin. Results expressed as mean \pm S.E.M. were obtained from six independent experiments.

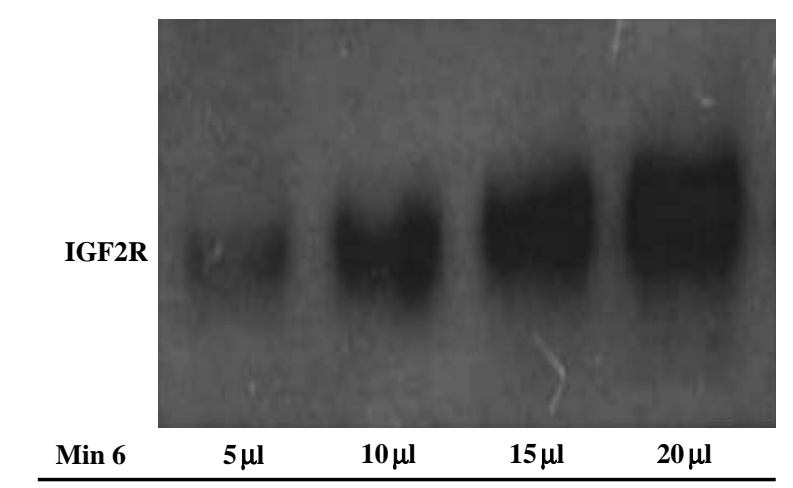

Figure 5 Western blotting analysis of the membrane fraction from Min 6 cells shows the expression of IGF2R. Min 6 cells were fractionated and membrane fractions were probed with IGF2R antibodies as described in the Materials and Methods section. Expression of IGF2R was raised with the increase in loading membrane protein from lane 1 to 4 running duplicated. Immunoblot analyses were repeated three times, showing similar results.

Effect of U73122, a PLC inhibitor, on the action of preptin in Min 6 cells

In preptin $\left(10^{-9} \mathrm{~mol} / \mathrm{l}\right)$-treated Min 6 cells, increase in insulin secretion was reduced by U73122 in a concentrationdependent manner from $10^{-7}$ to $10^{-5} \mathrm{~mol} / \mathrm{l}$ (Fig. 7). However, it was not modified by $10^{-5} \mathrm{~mol} / 1$ of $\mathrm{U} 73343$, the inactive PLC inhibitor that is widely used as negative control.

Effect of chelerythrine, a PKC inhibitor, on the action of preptin in Min 6 cells

In Min 6 cells treated with preptin $\left(10^{-9} \mathrm{~mol} / \mathrm{l}\right)$, as shown in Fig. 8, the concentration-dependent blockade of preptininduced insulin secretion was also observed by chelerythrine from $10^{-7}$ to $10^{-5} \mathrm{~mol} / \mathrm{l}$.

\section{Discussion}

This study shows that i.v. injection of preptin at a dose of $0.1 \mathrm{mg} / \mathrm{kg}$ triggers a decrease in blood glucose level in fasted rats challenged by glucose. However, similar injection of preptin failed to modify blood sugar levels in normal rats. Otherwise, blood insulin level was raised by similar injection of preptin in fasted rats challenged by glucose. Thus, an acute injection of preptin induces a decline in plasma level of glucose connected with insulin secretion during glucose challenge in rats.

Min 6 cells are widely used in the study of insulin secretion (Nakashima et al. 2012). Therefore, we studied this cell line instead of primary cultured pancreatic cells obtained from killed animals for understanding the effect of preptin on insulin secretion (Fig. 9). Actually, preptin caused a concentration-dependent increase in insulin secretion from Min 6 cells. This action of preptin is only induced in 


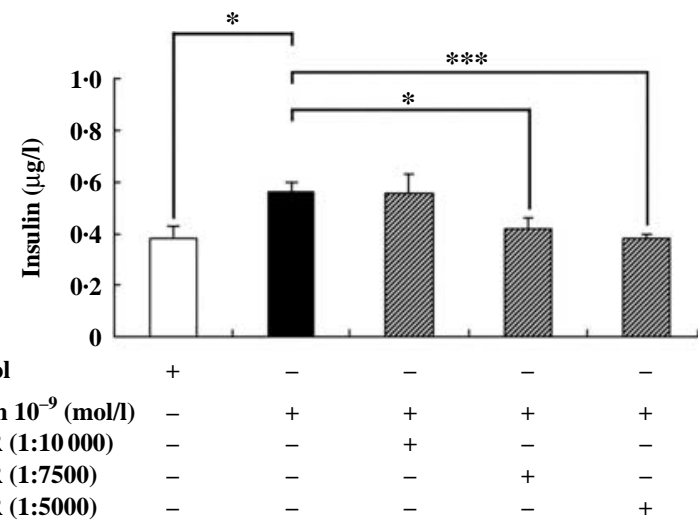

B

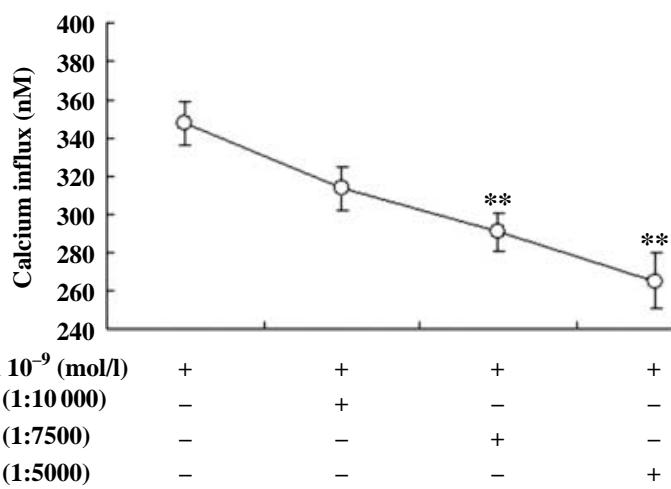

Figure 6 Effect of antibodies specific to IGF2R on the insulin secretion induced by preptin in Min 6 cells. (A) Changes in insulin secretion and (B) changes in calcium influx into Min 6 cells. Increase in insulin secretion by preptin $\left(10^{-9} \mathrm{~mol} / \mathrm{l}\right)$ was inhibited by antibodies specific to IGF2R in a concentration-dependent manner. Data represent mean \pm S.E.M. from six experiments. $* P<0 \cdot 05, * * P<0 \cdot 01,{ }^{* * *} P<0 \cdot 005$ compared with each control.

high-glucose conditions $(25 \mathrm{mmol} / \mathrm{l})$ but not in normal medium. There are many factors that affect the $\beta$-cell glucose sensitivity. One of the possible mechanism(s) for this is that preptin stimulating insulin secretion acts not only at the level of the amplifying pathway but also the triggering pathway; otherwise, the final effect would be that of an imbalance between these pathways. Moreover, under low concentrations of glucose, $\beta$-cells are not saturating for the glucose transporter and/or the expressed hexokinase, resulting in a reduction of glucose metabolism. High-glucose concentrations stimulate insulin release and increase glucose sensitivity in terms of insulin secretion, electrical activity, and $\mathrm{Ca}^{2+}$ signaling for changes in glucose metabolism (Rajan et al. 1990, Martín et al. 1999). Also, as shown in Fig. 4, this action of preptin is produced in a calcium-dependent manner. Otherwise, it has been demonstrated that glucose-induced insulin secretion is dependent on ATP-regulated $\mathrm{K}^{+}$channels (Rorsman \& Trube 1985).

Then, we used Min 6 cells to compare the insulin secretion action of preptin with glibenclamide, which is widely used to stimulate insulin secretion (Tominaga et al. 1995). The data indicate that Min 6 cells exposed to $10^{-6} \mathrm{~mol} / \mathrm{l}$ preptin can produce an effect on insulin secretion similar to that of glibenclamide at $10^{-6} \mathrm{~mol} / \mathrm{l}$. There was no significant difference between these two stimuli in insulin secretion. It has been established that glibenclamide acts as a blocker of ATP-regulated $\mathrm{K}^{+}$channels in pancreatic $\beta$-cells, thereby causing $\mathrm{Ca}^{2+}$ influx and a subsequent increase in $\left[\mathrm{Ca}^{2+}\right]_{\mathrm{i}}$. Glibenclamide can cause the dose-dependent inhibition of the $\mathrm{K}$ АтP channels to increase insulin secretion from $\beta$-cells (Tominaga et al. 1995). We found that an increase in insulin secretion by preptin was produced at a concentration similar to glibenclamide. The effective concentration of preptin seems higher as a peptide. It is possible that IGFRs are changed in cultured cells. Thus, preptin needs higher amounts to activate the IGFRs. Nevertheless, this is the first report that compared the efficiency of glibenclamide with preptin for insulin secretion in vitro.

As preptin is a fragment of a larger precursor (proIGF2), it is possible that preptin acts on cells through the IGF2R. IGF2R is a type-I transmembrane glycoprotein containing a large N-terminal extracellular region, a single membranespanning region, and a small cytoplasmic tail (Takasu et al. 1989, Ghosh et al. 2003). Actually, we are the first to identify the presence of IGF2R in Min 6 cells (Fig. 5). So far as we know, there is no direct antagonist of IGF2R. Thus, we used the IGF2R antibody to determine whether preptin acts via IGF2R. In this study, we found that insulin secretion of preptin was reduced when the IGF2R was blocked by antibodies, suggesting that the insulin secretion of preptin is mediated by the IGF2R pathway. However, it is possible that the IGF2R antibody bound to preptin directly. Thus, we investigated the changes of signals related to IGF2R in advance.

The signal transduction mechanisms involved IGF1- and IGF2-mediated induction of mobilization of $\mathrm{Ca}^{2+}$ from the endoplasmic reticulum with an activation of PLC. This effect

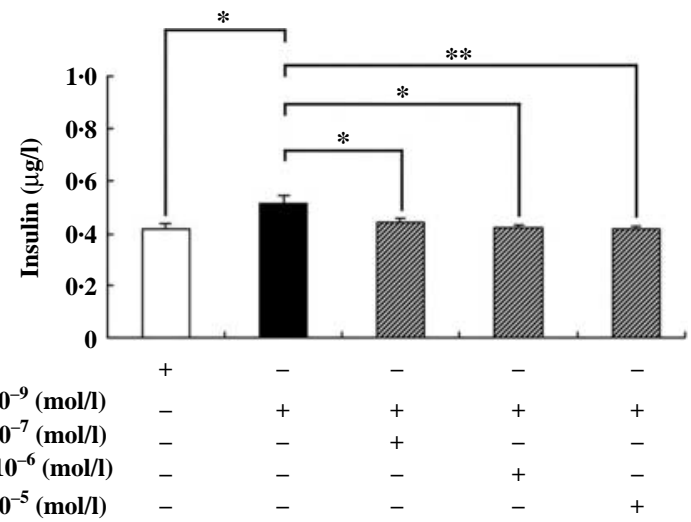

Figure 7 Effect of PLC inhibitor (U73122) on the insulin secretion induced by preptin in Min 6 cells. Action of preptin was reduced by $U 73122$ in a concentration-related manner. Data represent mean \pm S.E.M. from six experiments. ${ }^{*} P<0 \cdot 05,{ }^{* *} P<0 \cdot 01$ compared with each control. 


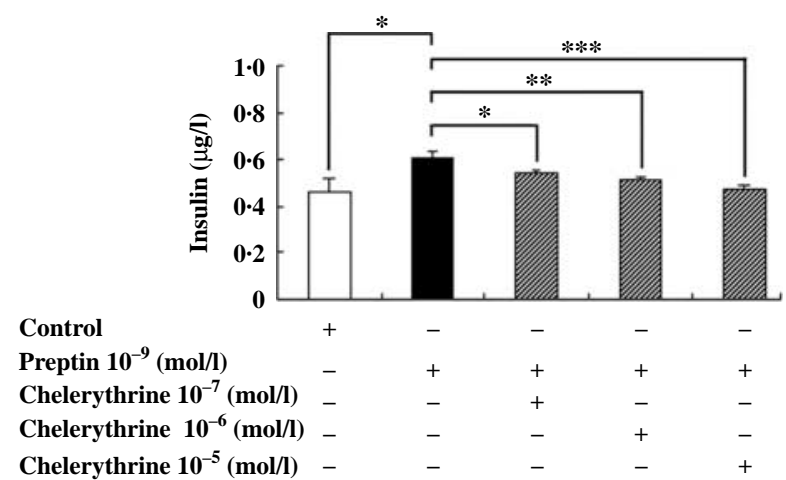

Figure 8 Effect of the PKC inhibitor chelerythrine on insulin secretion induced by preptin in Min 6 cells. Action of preptin was inhibited by chelerythrine in a concentration-related manner. Data represent mean \pm s.E.M. from six experiments. ${ }^{*} P<0 \cdot 05,{ }^{* *} P<0 \cdot 01$, *** $P<0 \cdot 005$ compared with each control.

of IGF1 or IGF2 on $\mathrm{Ca}^{2+}$ mobilization indicates that IGF1 or IGF2 increases inositol 1,4,5-triphosphate formation in different cell types (Rogers \& Hammerman 1988, Guse et al. 1992, Muto et al. 1997). In Min 6 cells and primary $\beta$-cells, PLC-linked agonists at low near physiological concentrations cause $\mathrm{Ca}^{2+}$ oscillations whose frequency is determined by the extracellular agonist concentration, whereas the amplitude remains constant (Gao et al. 1990, Cuthbertson \& Chay 1991, Konrad et al. 1994, Thomas et al. 1996, Zawalich \& Zawalich 1996). This result indicates that the cytosolic $\mathrm{Ca}^{2+}$ signal evoked by PLC-linked agonists might be primarily frequency encoded. Thus, we used a PLC inhibitor (U73122) to determine whether PLC is the pathway affected by preptin (Thomas et al. 1996). In this study, the stimulatory effect of preptin on insulin secretion was almost

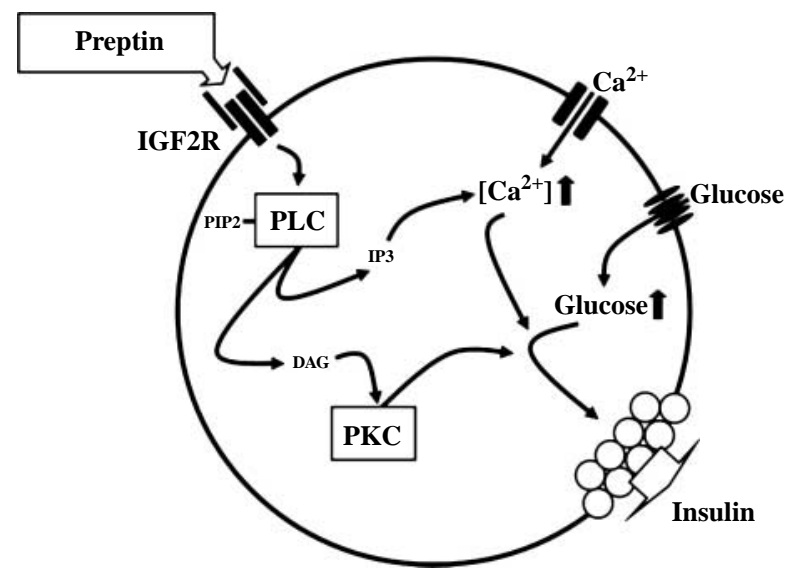

Figure 9 Hypothetical model for the regulation of insulin secretion by preptin and IGF2. Preptin influences the secretory process through the activation of IGF2 as a consequence of an influx of extracellular $\mathrm{Ca}^{2+}$. Receptor-operated non-nutrients that are coupled to PLC may activate $\mathrm{Ca}^{2+}$-dependent protein kinases by the IP3-induced release of $\mathrm{Ca}^{2+}$ from intracellular stores and activate conventional and/or novel isoforms of PKC by the generation of DAG. completely abrogated in Min 6 cells preincubated with U73122 at concentrations from $10^{-7}$ to $10^{-5} \mathrm{~mol} / \mathrm{l}$. The results indicate that the PLC pathway is involved in the actions of preptin after activation of IGF2R.

PKC is known to be activated and translocated to the plasma membrane during calcium signaling. The involvement of PKC has been previously implied in the regulation of PLC-generated $\left[\mathrm{Ca}^{2+}\right]_{\mathrm{i}}$ oscillations in several non-excitable cell types (Thomas et al. 1996, Nakashima et al. 2012). To understand the effects of PKC-mediated modulation of preptin-induced $\left[\mathrm{Ca}^{2+}\right]_{\mathrm{i}}$ oscillations and of PLC-induced $\left[\mathrm{Ca}^{2+}\right]_{\mathrm{i}}$ oscillations in insulin-producing cells, it is desirable to inhibit or inactivate PKC directly. The role of PKC was thus investigated using chelerythrine that can inhibit PKC in a competitive manner with respect to phosphate acceptor (Herbert et al. 1990). The effect of preptin enhancement on insulin secretion was sensitive to the PKC inhibitor. In the presence of chelerythrine, the action of preptin to stimulate insulin secretion of Min 6 cells was attenuated in a concentration-dependent manner. These results demonstrate that the activation of PKC could be a potential mechanism mediating the stimulation of insulin secretion from $\beta$-cells in response to preptin. Taken together, the involvement of the PLC-PKC pathway in the regulation of insulin after stimulating IGF2R by preptin is evident in Min 6 cells (Fig. 9).

In conclusion, we suggest that preptin, an endocrine peptide secreted from pancreatic $\beta$-cells, can activate IGF2R linked to the PKC/PLC pathway to induce calciumdependent insulin secretion under high-glucose conditions. This finding provides new insight into the autocrine action of preptin. Also, activation of IGFRs by preptin is still not observed in other tissues and this shall be investigated in the future.

\section{Declaration of interest}

The authors declare that there is no conflict of interest that could be perceived as prejudicing the impartiality of the research reported.

\section{Funding}

This work was funded partially by the Young Researcher Overseas Visits Program for Vitalizing Brain Circulation by the Japan Society for the Promotion of Science.

\section{Acknowledgements}

The authors gratefully acknowledge Prof. Susumu Seino (Kobe University, Kobe, Japan) for the kind supply of Min 6 cell lines.

\section{References}

Baron AD 1998 Postprandial hyperglycaemia and $\alpha$-glucosidase inhibitors. Diabetes Research and Clinical Practice 40 51-55. (doi:10.1016/S01688227(98)00043-6) 
Bird GS, Rossier MF, Obie JF \& Putney JW Jr 1993 Sinusoidal oscillations in intracellular calcium requiring negative feedback by protein kinase $\mathrm{C}$. Journal of Biological Chemistry 268 8425-8428.

Buchanan CM, Phillips AR \& Cooper GJ 2001 Preptin derived from proinsulin-like growth factor II (proIGF-II) is secreted from pancreatic islet $\beta$-cells and enhances insulin secretion. Biochemical Journal $360431-439$. (doi:10.1042/0264-6021:3600431)

Codazzi F, Teruel MN \& Meyer T 2001 Control of astrocyte $\mathrm{Ca}^{2+}$ oscillations and waves by oscillating translocation and activation of protein kinase $\mathrm{C}$. Current Biology 11 1089-1097. (doi:10.1016/S0960-9822(01)00326-8)

Cuthbertson KS \& Chay TR 1991 Modelling receptor-controlled intracellular calcium oscillators. Cell Calcium 12 97-109. (doi:10.1016/01434160(91)90012-4)

Gao ZY, Drews G, Nenquin M, Plant TD \& Henquin JC 1990 Mechanisms of the stimulation of insulin release by arginine-vasopressin in normal mouse islets. Journal of Biological Chemistry 265 15724-15730.

Garcia MC, Hermans MP \& Henquin JC 1988 Glucose-, calcium- and concentration-dependence of acetylcholine stimulation of insulin release and ionic fluxes in mouse islets. Biochemical Journal 254 211-218.

Ghosh P, Dahms NM \& Kornfeld S 2003 Mannose 6-phosphate receptors: new twists in the tale. Nature Reviews. Molecular Cell Biology 4 202-212. (doi:10.1038/nrm1050)

Guse AH, Kiess W, Funk B, Kessler U, Berg I \& Gercken G 1992 Identification and characterization of insulin-like growth factor receptors on adult rat cardiac myocytes: linkage to inositol 1,4,5-trisphosphate formation. Endocrinology 130 145-151. (doi:10.1210/en.130.1.145)

Harndahl L, Jing XJ, Ivarsson R, Degerman E, Ahren B, Manganiello VC, Renstrom E \& Holst LS 2002 Important role of phosphodiesterase 3B for the stimulatory action of cAMP on pancreatic $\beta$-cell exocytosis and release of insulin. Journal of Biological Chemistry 277 37446-37455. (doi:10.1074/ jbc.M205401200)

Herbert JM, Augereau JM, Gleye J \& Maffrand JP 1990 Chelerythrine is a potent and specific inhibitor of protein kinase C. Biochemical and Biophysical Research Communications 172 993-999. (doi:10.1016/0006291X(90)91544-3)

Kawabata S, Tsutsumi R, Kohara A, Yamaguchi T, Nakanishi S \& Okada M 1996 Control of calcium oscillations by phosphorylation of metabotropic glutamate receptors. Nature 383 89-92. (doi:10.1038/383089a0)

Konrad RJ, Major CD \& Wolf BA 1994 Diacylglycerol hydrolysis to arachidonic acid is necessary for insulin secretion from isolated pancreatic islets: sequential actions of diacylglycerol and monoacylglycerol lipases. Biochemistry 33 13284-13294. (doi:10.1021/bi00249a015)

Lee PY, Chen W, Liu IM \& Cheng JT 2007 Vasodilatation induced by sinomenine lowers blood pressure in spontaneously hypertensive rats. Clinical and Experimental Pharmacology \& Physiology 34 979-984. (doi:10.1111/j.1440-1681.2007.04668.x)

Martín F, Andreu E, Rovira JM, Pertusa JA, Raurell M, Ripoll C, Sanchez-Andrés JV, Montanya E \& Soria B 1999 Mechanisms of glucose hypersensitivity in $\beta$-cells from normoglycemic, partially pancreatectomized mice. Diabetes 48 1954-1961. (doi:10.2337/diabetes.48.10.1954)

Muto Y, Nagao T \& Urushidani T 1997 The putative phospholipase C inhibitor U73122 and its negative control, U73343, elicit unexpected effects on the rabbit parietal cell. Journal of Pharmacology and Experimental Therapeutics 282 1379-1388.

Nakashima K, Shimoda M, Hamamoto S, Tatsumi F, Hirukawa H, Tawaramoto K, Kanda Y \& Kaku K 2012 Self-inducible secretion of glucagon-like peptide-1 (GLP-1) that allows MIN6 cells to maintain insulin secretion and insure cell survival. Molecular and Cellular Endocrinology 349 281-288. (doi:10.1016/j.mce.2011.11.008)

Rajan AS, Aguilar-Bryan L, Nelson DA, Yaney GC, Hsu WH, Kunze DL \& Boyd AE III 1990 Ion channels and insulin secretion. Diabetes Care 13 340-363. (doi:10.2337/diacare.13.3.340)

Regazzi R, Li GD, Deshusses J \& Wollheim CB 1990 Stimulus-response coupling in insulin-secreting HIT cells. Effects of secretagogues on cytosolic $\mathrm{Ca}^{2+}$, diacylglycerol, and protein kinase C activity. Journal of Biological Chemistry 265 15003-15009.

Rogers SA \& Hammerman MR 1988 Insulin-like growth factor II stimulates production of inositol trisphosphate in proximal tubular basolateral membranes from canine kidney. PNAS 85 4037-4041. (doi:10.1073/pnas. 85.11.4037)

Rorsman P \& Trube G 1985 Glucose dependent $\mathrm{K}^{+}$-channels in pancreatic $\beta$-cells are regulated by intracellular ATP. Pfiugers Archiv: European Journal of Physiology 405 305-309. (doi:10.1007/BF00595682)

Schofl C, Schulte P, Rossig L, von zur Muhlen A \& Brabant G 1995 Vasopressin induces frequency-modulated repetitive calcium transients in single insulin-secreting hit cells. Molecular and Cellular Endocrinology 108 185-192. (doi:10.1016/0303-7207(95)03474-L)

Takasu N, Takasu M, Komiya I, Nagasawa Y, Asawa T, Shimizu Y \& Yamada T 1989 Insulin-like growth factor I stimulates inositol phosphate accumulation, a rise in cytoplasmic free calcium, and proliferation in cultured porcine thyroid cells. Journal of Biological Chemistry 264 18485-18488.

Thomas AP, Bird GS, Hajnoczky G, Robb-Gaspers LD \& Putney JW Jr 1996 Spatial and temporal aspects of cellular calcium signaling. FASEB Journal 10 1505-1517.

Tominaga M, Horie M, Sasayama S \& Okada Y 1995 Glibenclamide, an ATP-sensitive $\mathrm{K}^{+}$channel blocker, inhibits cardiac cAMP-activated $\mathrm{Cl}^{-}$ conductance. Circulation Research 77 417-423. (doi:10.1161/01.RES.77. 2.417)

Woods NM, Cuthbertson KS \& Cobbold PH 1987 Agonist-induced oscillations in cytoplasmic free calcium concentration in single rat hepatocytes. Cell Calcium 8 79-100.

Yang G, Li L, Chen W, Liu H, Boden G \& Li K 2009 Circulating preptin levels in normal, impaired glucose tolerance, and type 2 diabetic subjects. Annals of Medicine 41 52-56. (doi:10.1080/ 07853890802244142)

Young SH, Wu SV \& Rozengurt E $2002 \mathrm{Ca}^{2+}$-stimulated $\mathrm{Ca}^{2+}$ oscillations produced by the $\mathrm{Ca}^{2+}$-sensing receptor require negative feedback by protein kinase C. Journal of Biological Chemistry 277 46871-46876. (doi:10.1074/jbc.M207083200)

Zawalich WS \& Zawalich KC 1996 Regulation of insulin secretion by phospholipase C. American Journal of Physiology 271 409-416.

Received in final form 6 July 2012

Accepted 11 July 2012

Made available online as an Accepted Preprint 11 July 2012 